\title{
Anal HIV DNA is associated with high-risk HPV genotypes in anal cytology specimens obtained for anal neoplasia screening
}

\author{
Bruce Shiramizu*, Chin-Yuan Liang ${ }^{1}$, Xumei Zhu², Melissa Agsalada', lan Nagata', Kellie Kitamura', Jeffrey Killeen ${ }^{3}$, \\ J Michael Berry ${ }^{4}$, Marc Goodman²
}

From 13th International Conference on Malignancies in AIDS and Other Acquired Immunodeficiencies (ICMAOI)

Bethesda, MD, USA. 7-8 November 2011

\section{Purpose}

High-grade anal neoplasia (AN) is associated with highrisk human papillomavirus (HPV) genotypes and is the precursor to anal cancer. Individuals infected with human immunodeficiency virus type 1 (HIV) continue to be at increased risk for $\mathrm{AN}$ even while on effective antiretroviral therapy (ART) with undetectable HIV RNA levels. The study was undertaken to assess HIV DNA from anal cytology specimens to determine if HIV DNA copy number was a factor for presence of high risk HPV genotypes.

\section{Material and methods}

Anal cytology specimens were obtained as part of an AN study according to guidelines approved by the local institutional review board. Anal HPV genotype, HIV DNA copy numbers, and cytology were obtained for each specimen. High-risk HPV genotypes included 16, $18,31,33,35,39,45,51,52,56,58,59$, and 68 . Analysis was performed by logistic regression model with high HPV risk as the response and HIV DNA copy numbers, anal Pap cytology results, and nadir CD4 cell counts as predictors. Lemeshow goodness-of-fit test was then performed to check model fit. Similar procedure was performed in sub-cohort of undetectable HIV RNA patients.

\section{Results}

46 specimens were available from 38 males and 8 females. $52.2 \%$ of the specimens were negative for any HPV with

\footnotetext{
* Correspondence: bshirami@hawaii.edu

'University of Hawaii, Hawaii Center of AIDS, Honolulu, HI, USA

Full list of author information is available at the end of the article
}

$52.6 \%$ of males being HPV-positive compared to $25 \%$ of females. Of 46 specimens, 42 patients had undetectable HIV RNA level. The odds of having high-risk HPV genotypes among subjects with $(x+100)$ copies of HIV DNA was 1.161 times the odds among subjects with $\mathrm{x}$ copies of HIV DNA ( $p=0.013)$. Inclusion of nadir CD4 count in the logistic regression model did not predict HPV risk. Distributions of HIV DNA were statistically different between normal and abnormal anal cytologies $(\mathrm{p}=0.009)$; median and interquartile HIV DNA copy numbers for abnormal and normal cytologies 792 (38-2100) and 27.5 (10-225), respectively, Figure 1 . Anal cytology results were also associated with HPV risk $(\mathrm{p}=0.034)$. Patients with undetectable HIV RNA ( $\mathrm{n}=42)$ had similar findings.

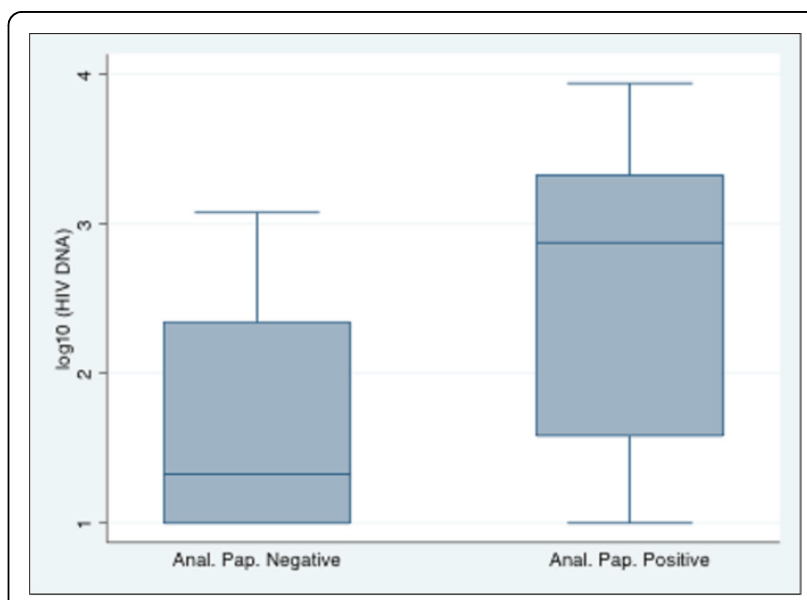

Figure 1 Differences in HIV DNA distributions between normal and atypical anal Pap groups $(p=0.011)$. 


\section{Conclusions}

Individuals with higher HIV DNA copies in anal specimens were more likely to have high-risk HPV genotypes independent of nadir CD4 cell count. Abnormal anal cytologies were also associated with high-risk HPV. The association of HIV DNA copy number in anal specimens needs validation in future studies to determine the role in the pathogenesis of AN and high risk HPV. Grant support: RR011091, RR026136, CA121947, CA143727, CA096254.

\section{Author details}

${ }^{1}$ University of Hawaii, Hawaii Center of AIDS, Honolulu, HI, USA. ${ }^{2}$ University of Hawaii Cancer Center, Honolulu, HI, USA. ${ }^{3}$ University of Hawaii, Hawaii Department of Pathology, Honolulu, HI, USA. ${ }^{4}$ University of California, San Francisco, CA, USA.

Published: 19 April 2012

doi:10.1186/1750-9378-7-S1-P4

Cite this article as: Shiramizu et al:: Anal HIV DNA is associated with

high-risk HPV genotypes in anal cytology specimens obtained for anal neoplasia screening. Infectious Agents and Cancer 2012 7(Suppl 1):P4.

Submit your next manuscript to BioMed Central and take full advantage of:

- Convenient online submission

- Thorough peer review

- No space constraints or color figure charges

- Immediate publication on acceptance

- Inclusion in PubMed, CAS, Scopus and Google Scholar

- Research which is freely available for redistribution

Submit your manuscript at www.biomedcentral.com/submit 